\title{
UČITELJSKA UVJERENJA O VRIJEDNOSTIMA INKLUZIVNOG OBRAZOVANJA
}

\author{
SANJA SKOČIĆ MIHIĆ ${ }^{1}$, IRIS GABRIĆ ${ }^{2}$, SANDRA BOŠKOVIĆ \\ ${ }^{1}$ Učiteljski fakultet Sveučilišta u Rijeci, ${ }^{2}$ Osnovna škola Kraljevica, ${ }^{3}$ Fakultet zdravstvenih studija Sveučilišta u Rijeci, \\ kontakt: sandra.centar@gmail.com
}

Primljeno: 21.12.2015.

Izvorni znanstveni rad

Prihvaćeno: 31.3.2016.

UDK: $376.1-056.340$

Sažetak: Hrvatska obrazovna politika inkluzivna je i usmjerena na promicanje inkluzivnih vrijednosti u zajednici. Učiteljska uvjerenja i stavovi prema inkluzivnom obrazovanju ključni su za uspješno obrazovanje učenika s teškoćama u redovnim razredima. U radu se polazi od hipoteze da učitelji smatraju da inkluzivno obrazovanje podjednako doprinosi razvoju učenika s teškoćama $i$ njihovih tipičnih vršnjaka te da se učitelji međusobno razlikuju u odnosu na neka socio-demografska obilježja.

U istraživanju su sudjelovala 274 učitelja iz dvije županije u Republici Hrvatskoj. Korišten je preveden i prilagođen upitnik Učiteljskih uvjerenja o inkluziji učenika s teškoćama (Teachers' Opinions about the Inclusion of Children with Moderate to Severe Special Needs in General Education Settings (Linn i Coelho da Silva, 2014). Značajnom redukcijom varijabli dobivena je skala učiteljskih uvjerenja o vrijednostima inkluzivnog obrazovanja, dobrih metrijskih karakteristika, koja sadrži 2 faktora: (1) Inkluzivno obrazovanje doprinosi razvoju tipičnih učenika i (2) Inkluzivno obrazovanje doprinosi razvoju učenika s teškoćama.

Učitelji se slažu da inkluzivno obrazovanje doprinosi razvoju tipičnih učenika, a djelomično se slažu da doprinosi i razvoju učenika s teškoćama. Viša razina slaganja glede tvrdnje da inkluzivno obrazovanje doprinosi razvoju tipičnih učenika prisutna je kod mlađih učiteljas višom razinom obrazovanja, dok učitelji koji su slušali kolegij o inkluzivnom obrazovanju tijekom inicijalnog obrazovanja u većoj mjeri smatraju da inkluzivno obrazovanje doprinosi i razvoju učenika s teškoćama,

Upravo uvjerenje da inkluzivno obrazovanje doprinosi razvoju inkluzivnih vrijednosti kod svih učenika te da učenici s teškoćama mogu akademski i socio-emocionalno napredovati u redovnim razredima, snažno određuje spremnost učitelja za korištenje prilagodbi u poučavanju učenika s teškoćama i razvijanje inkluzivnog razrednog ozračja. Uz razvoj kompetencija za poučavanje u inkluzivnoj nastavi, neophodno je i oblikovanje takvih uvjerenja u učitelja koja promoviraju inkluzivne vrijednosti.

Ključne riječi: inkluzivno obrazovanje, inkluzivne vrijednosti, učitelji, uvjerenja.

\section{UVOD}

Inkluzivno obrazovanje odnosi se na odgoj i obrazovanje učenika s teškoćama i tipičnih učenika u redovitim školama i u posljednja dva desetljeća dominira u odgojno-obrazovnoj politici razvijenih zemalja (Rafferty i sur., 2010). Hrvatska obrazovna politika inkluzivna je, usklađena s međunarodnim konvencijama (Konvencija o pravima osoba s invaliditetom, 2007) te osigurava uključivanje učenika $\mathrm{s}$ teškoćama u redovni odgojno-obrazovni sustav (Državni pedagoški standard osnovnoškolskog odgoja i obrazovanja, 2008; Pravilnik o osnovnoškolskom odgoju i obrazovanju učenika s teškoćama u razvoju, 2015; Zakon o odgoju i obrazovanju u osnovnoj i srednjoj školi, 2008, 2009, 2010, 2011, 2012, 2013, 2014; Nacionalni kurikulum za rani i predškolski odgoj i obrazovanje, 2014; Nacionalni okvirni kurikulum za predškolski odgoj i obrazovanje te opće obvezno i srednjoškolsko obrazovanje, 2001). Učenici s teškoćama su: (1) učenici s teškoćama u razvoju, (2) učenici s teškoćama u učenju, problemima u ponašanju i emocionalnim problemima i (3) učenici s teškoćama uvjetovanim odgojnim, socijalnim, ekonomskim, kulturalnim i jezičnim čimbenicima (Zakon o odgoju i obrazovanju u osnovnoj i srednjoj školi, 2008). Učenici s teškoćama u razvoju su učenici koji imaju utvrđeni stupanj i vrstu teškoće u psihofizičkom razvoju, kao npr. oštećenje vida ili sluha, govorno-glasovnojezične komunikacije i specifičnih teškoća u učenju, motorike, intelektualnih sposobnosti, poremećaje u ponašanju, autizam ili više vrsta teškoća po propisima iz socijalne skrbi, a uključeni su u redovitu ili 
posebnu osnovnoškolsku ustanovu i nastavu prate po redovitom, individualiziranom ili posebnom programu (Pravilnik o osnovnoškolskom i srednjoškolskom odgoju i obrazovanju učenika s teškoćama u razvoju, 2015). Učenici s teškoćama čine vrlo heterogenu skupinu; među njima postoje brojne razlike s obzirom na vrstu i stupanj teškoća, kao i odjecima teškoća i socijalnog okruženja na razne aspekte socijalnih interakcija (Žic Ralić i Ljubas, 2013). Redovno osnovnoškolsko obrazovanje više je nego ikada dostupno većini učenika s teškoćama, tako da se danas tek mali broj njih školuje u posebnim ustanovama. Zakonski propisi u posljednjem desetljeću (Konvencija o pravima osoba s invaliditetom, 2007, Zakon o odgoju i obrazovanju u osnovnoj i srednjoj školi, 2008, Pravilnik o osnovnoškolskom i srednjoškolskom odgoju i obrazovanju učenika s teškoćama u razvoju, 2015), nakon obrazovne politike integracije, normiraju inkluzivno obrazovanje. U skladu sa socijalnim modelom društva prema osobama s invaliditetom novi zakonski propisi omogućuju uključivanje velikog broja učenika s teškoćama jer definiraju različite oblike podrške koje odgojno-obrazovni sustav treba osigurati ovim učenicima. Oni uključuju usmjerenost na potrebe učenika i prilagodbe u odgojno-obrazovnom okruženju kao temeljni pristup u socijalnom modelu, a ne na teškoću, što je dominiralo u medicinskom modelu ili modelu deficita (Skočić Mihić, 2011). Učenici s teškoćama u razvoju radi "osjetilnih, motoričkih, jezično-govorno-glasovnih i komunikacijskih, kognitivnih, psiholoških, emocionalnih i interakcijskih sposobnosti i vještina izvedbe aktivnosti svakodnevnoga života" trebaju podršku u odgojnoobrazovnom procesu da bi mogli napredovati u skladu sa svojim mogućnostima, interesima i potrebama (Pravilnik o osnovnoškolskom i srednjoškolskom odgoju i obrazovanju učenika s teškoćama u razvoju, 2015). Nekad okarakterizirani kao "manje sposobni" i oni koji se školuju u posebnom sustavu, s razvojem koncepta inkuzivnog obrazovanja učenici s teškoćama u razvoju danas su uključeni u redovne razrede (Florian i Linklater, 2010). Današnje razrede čine heterogene skupine učenika različitih sposobnosti, mogućnosti i interesa. Upravo je navedena različitost prilika za razvoj vrijednosti prihvaćanja, međusobnog razumijevanja, zajedništva, pružanja podrške i razvoja ljudskih vrednota. Inkluzivne vrijednosti "promoviraju" interkulturalne kompetencije, demo- kratske vrijednosti i temeljna ljudska prava, boreći se protiv diskriminacije, potičući sve učenike na pozitivne socijalne odnose s vršnjacima s teškoćama (Council Conclusions on a strategic framework for European cooperation in education and training “ET 2020”, 2009). Prihvaćanjem različitosti, naglašavanjem sličnosti među djecom, vlastitih vrijednosti i pripadnosti razredu, kod učenika se razvija međusobna povezanost i osjećaj sigurnosti (Meadan i Monda-Amaya, 2008). Za uspostavu podržavajućeg i inkluzivnog razrednog ozračja ključni su podržavajući odnosi između učenika, učitelja i članova obitelji (Bouillet i Kudek Mirošević, 2015). Takvo razredno ozračje inkluzivno je razredno ozračje, a karakterizira ga uspostavljanje pozitivnih socijalnih interakcija među svim učenicima u razredu, kao i između učitelja i učenika. Učitelji “orkestiraju razredno ozračje" i imaju ključnu ulogu u razvoju pozitivnog (Pavri i Hegwer-DiVita, 2015) i inkluzivnog razrednog ozračja.

Uspješna implementacija inkluzivog obrazovanja u velikoj mjeri ovisi o učiteljskim kompetencijama za poučavanje $u$ inkluzivnim razredima i njihovim uvjerenjima o tim kompetencijama (Winter, 2006). Brojna istraživanja identificirala su osjećaj nedovoljne kompetentnosti učitelja za rad s učenicima s teškoćama (Skočić Mihić, 2011), nedostatak znanja i vještina za poučavanje u inkluzivnim razredima (Florian i Linklater, 2010). Ako se obrazuju za poučavanje u homogenim razredima i monoetničkim školama, zbog nedovoljnih informacija o učenicima s teškoćama ili nedovoljnog iskustva, učitelji imaju negativne stavove prema obrazovanju ovih učenika (Hanak i Dragojević, 2002; Hrnjica i Sretenov, 2003; Vujačić, 2011; prema Karić, 2014 i sur.). Viša razina kompetencija učitelja za poučavanje u inkluzivnoj nastavi povezana je s pozitivnijim stavovima (Everington i sur., 1999). Kako bi razvili osjećaj kognitivne i emocionalne kompetentnosti za rad u inkluzivnoj nastavi, studentima je potrebno primjereno znanje o metodama i načinima rada s učenicima s teškoćama, kao i iskustveno učenje, koje mogu stjecati volontiranjem s ovom djecom (Skočić Mihić i sur., 2011, Skočić Mihić, i sur., 2014). Studenti na studij dolaze s uvjerenjima o učenju i poučavanju koja oblikuju njihova ponašanja i aktiviraju se u različitim situacijama (Korthagen, 2004). Također, nji- 
hova uvjerenja određuju kompetencije (Korthagen, 2004) o kojima ovisi uspješnost inkluzivne nastave. Uvjerenja su misaoni konstrukti prihvaćanja nečega kao istinitoga, bez nužne neposredne i rigorozne provjere, često duboko ukorijenjena $\mathrm{i}$ snažno emocionalno obojena (Domović i Vizek Vidović, 2013). Kohezivne su cjeline ranijih iskustava, uzora, potreba, vrijednosti, osjećaja, slika i rutina, koji su, često nesvjesno, izazvani konkretnim situacijama (Korthagena i Lagerwerf, 1996). Sklop su konceptualnih predodžbi o općim znanjima, pojavama, ljudima i događajima vezanim uz profesionalni kontekst, njihovom razumijevanju, pretpostavkama ili propozicijama koje učitelji smatraju istinitima (Samuel i Stephens, 2000). Uvjerenja su dinamički proces (Olsen, 2008, Zheng, 2009) i uključuju utjecaje iz neposrednoga okruženja, prijašnje poimanje sebe, socijalnu poziciju i sustav značenja (Olsen, 2008). Ovise o sustavu vrijednosti u kojem se učitelj razvija kroz obrazovanje, djelovanje i iskustva. Iako duboko ukorijenjena, uvjerenja nisu nepromjenjiva i dio su profesionalnog identiteta koji se razvija kroz profesionalnu socijalizaciju tijekom cijelog života razvijajući profesionalnu sliku o sebi (Beijaard i sur., 2004). Profesionalna uvjerenja su propusne i dinamičke strukture koje su kao filtar kroz koji se nova znanja i iskustva selektiraju (Zheng, 2009) i kao takva u značajnoj mjeri određuju kako će se učitelji ponašati i kako će poučavati (Richardson, 1996). Profesionalna slika o sebi uključuje osjećaj za vlastite ciljeve, odgovornosti, stil rada i poučavanja, učinkovitost, stupanj zadovoljstva i vlastito planiranje razvoja karijere (Kosnik i Beck, 2009). Profesionalno uvjerenje učitelja o ulozi u inkluzivnom obrazovanju značajno određuje kompetencije (znanja, vještine i stavove) i ponašanja (Korthagen, 2004). Gotovo svi učitelji poučavaju u suvremenim inkluzivnim razredima s oskudnom razinom stečenih kompetencija tijekom inicijalnog obrazovanja, a njihova uvjerenja i stavovi ključni su za uspješno poučavanje učenika s teškoćama.

\section{CILJ ISTRAŽIVANJA}

Istraživački problem ovog rada usmjeren je, stoga, na učiteljska uvjerenja o inkluzivnom obrazovanju i njegovom doprinosu razvoju sve djece. Definirana su dva cilja: (1) utvrditi latentnu struk- turu učiteljskih uvjerenja o doprinosu inkluzivnog obrazovanja razvoju učenika s teškoćama i razvoju tipičnih vršnjaka, te (2) provjeriti postoje li razlike među učiteljima u odnosu na neka socio-demografska obilježja: dob, godine staža, mjesto rada i program studija.

\section{HIPOTEZE}

Temeljem teorijskih spoznaja, u radu se polazi od sljedećih hipoteza:

H.1. Učitelji se slažu da inkluzivno obrazovanje doprinosi razvoju svih učenika.

H.2. Postoje statistički značajne razlike u razini slaganja učitelja s tvrdnjom da inkluzivno obrazovanje doprinosi razvoju svih učenika u odnosu na dob, godine radnog staža, vrstu i sadržaj studijskog programa, a ne postoje u odnosu na županiju u kojoj rade.

H.2.1. Mlađi učitelji iskazuju višu razinu slaganja s tvrdnjom da inkluzivno obrazovanje doprinosi razvoju učenika s teškoćama i razvoju tipičnih vršnjaka, u odnosu na starije učitelje.

H.2.2. Učitelji s manje godina radnog staža iskazuju višu razinu slaganja s tvrdnjom da inkluzivno obrazovanje doprinosi razvoju učenika s teškoćama i razvoju tipičnih vršnjaka, u odnosu na učitelje s više godina radnog staža.

H.2.3. Učitelji se ne razlikuju u razini slaganja s tvrdnjom da inkluzivno obrazovanje doprinosi razvoju svih učenika.

H.2.4. Učitelji koji su završili sveučilišni studij iskazuju višu razinu slaganja s tvrdnjom da inkluzivno obrazovanje doprinosi razvoju učenika s teškoćama i razvoju tipičnih vršnjaka, u odnosu na učitelje koji su završili stručni studij.

H.2.4. Učitelji koji su slušali kolegij o inkluzivnom obrazovanju iskazuju višu razinu slaganja s tvrdnjom da inkluzivno obrazovanje doprinosi razvoju učenika s teškoćama i razvoju tipičnih vršnjaka, u odnosu na učitelje koji su završili stručni studij. 


\section{METODE RADA}

\section{Uzorak ispitanika}

Prigodan uzorak učitelja čine 292 učitelja predmetne i razredne nastave zaposlena u osnovnim školama Primorsko-goranske i Međimurske županije. Prosječna dob ispitanika je 42 godine, $\mathrm{s}$ prosječno 17 godina radnoga staža na mjestu učitelja, od čega je 52\% učitelja predmetne, a $48 \%$ je učitelja razredne nastave. Prema spolu, $90 \%$ je učiteljica, a $10 \%$ učitelja, od čega je $48 \%$ završilo četverogodišnji sveučilišni studij, 27\% dvogodišnji, 13\% četverogodišnji stručni studij, $10 \%$ petogodišnji sveučilišni studij, a jedan učitelj završio je poslijediplomski studij. Dvije trećine učitelja (65\%) navodi da nisu odslušali obvezni kolegij Inkluzivni odgoj i obrazovanje (raniji naziv Odgoj djece s posebnim potrebama, Specijalna pedagogija i sl.), iako je on obvezni kolegij u studijskom programu više od 30 godina. Također, $70 \%$ njih izjavljuje da su se stručno usavršavali za rad s djecom s teškoćama. Gotovo svi učitelji (93\%) navode da su radili s djecom s teškoćama, a polovica učitelja $(48 \%)$ trenutno u razredu ima učenika s teškoćama u razvoju.

\section{Mjerni instrument}

Upitnikom Socio-demografski podaci prikupljeni si podaci koji su se odnosili na dob, godine staža, mjesto rada učitelja te vrstu i sadržaj studijskog programa kojeg su završili.

Skala Učiteljskih uvjerenja o vrijednostima inkluzivnog obrazovanja sadrži 10 čestica koje ispituju uvjerenja o prednostima uključivanja učenika s teškoćama u redovne razrede za učenike $\mathrm{s}$ teškoćama i bez njih. Uz dopuštenje autora, čestice upitnika A Survey of Teachers' Opinions About the Inclusion of Children with Moderate to Severe Special Needs in General Education Settings (Linn i Coelho da Silva, 2014), korištene u ovom istraživanju, prevedene su i prilagođene. Učitelji su procjenjivali stupanj slaganja s tvrdnjama na skali Likertovog tipa od 5 stupnjeva: 1-uopće se ne slažem, 2-ne slažem se, 3-djelomično se slažem, 4-slažem se, 5-u potpunosti se slažem. Pouzdanost subskala provjerena je metodom unutarnje konzistencije: Cronbach alfa koeficijent iznosi 0,823 za oba ekstrahirana faktora. Visok raspon rezultata na subskalama ukazuje na visoku osjetljivost skale.

\section{Način provođenja istraživanja}

Istraživanje je provedeno tijekom ožujka 2015. godine u 27 osnovnih škola na području Primorskogoranske i Međimurske županije. Formiran je prigodni uzorak škola iz navedenih županija te je ravnateljima škola elektroničkom poštom ili osobno upućena zamolba za sudjelovanjem u istraživanju. Nakon dobivene suglasnosti ravnatelja, svim zaposlenim učiteljima u odabranim školama dostavljeni su upitnici. Učiteljima su prije ispunjavanja upitnika dane upute i objašnjena im je svrha i cilj ovoga istraživanja. Sudjelovanje u istraživanju bilo je na dobrovoljnoj bazi te je osigurana anonimnost podataka na način da se podaci u upitniku ne mogu povezati sa sudionicima. Od ukupno 650 odaslanih upitnika, $45 \%$ bilo ih je valjano ispunjenih.

\section{Metode obrade podataka}

Izračunati su osnovni statistički parametri na česticama subskala (frekvencije, aritmetičke sredine i standardne devijacije). Normalnost distribucija rezultata ispitana je Kolmogorov-Smirnovljevim testom. Za provjeru prvog cilja i utvrđivanja latentnog prostora Skale te testiranje prve hipoteze korištena je faktorska analiza. Analizama varijance testirala se druga hipoteza te su se ispitale razlike u učiteljskim uvjerenjima o vrijednostima inkluzivnog obrazovanja u odnosu na socio-demografske značajke učitelja. Za provođenje analiza varijance zadovoljeni su preduvjeti: normalnosti distribucije rezultata, više od 30 ispitanika u skupini i homogenost varijance.

\section{REZULTATI I RASPRAVA}

U Tablici 1 prikazani su osnovni statistički pokazatelji učiteljskih uvjerenja o vrijednostima inkluzivnog obrazovanja.

$\mathrm{Na}$ svim česticama postignuti su minimalni i maksimalni rezultati osim na 2 čestice ("omogućava interakcije u miješanim skupinama koje potiču razumijevanje i prihvaćanje različitosti među učenicima” i "može doprinijeti razvoju učenicima tipičnog razvoja”) na kojima je minimalni rezultat 2 . 
Tablica 1. Osnovni statistički pokazatelji na Skali Učiteljska uvjerenja o vrijednostima inkluzivnog obrazovanja

\begin{tabular}{|c|c|c|c|}
\hline Inkluzivno obrazovanje doprinosi razvoju tipičnih učenika & $\mathbf{N}$ & $\mathbf{M}$ & SD \\
\hline prisutnost učenika s teškoćama utječe na promicanje i prihvaćanje razlika kod pojedinih učenika & 281 & 4,17 & 836 \\
\hline $\begin{array}{l}\text { omogućava interakcije u miješanim skupinama koje potiču razumijevanje i prihvaćanje različitosti među } \\
\text { učenicima }\end{array}$ & 283 & 4,11 & ,759 \\
\hline ima osnovni cilj osjećaj socijalne prihvaćenost & 285 & 3,94 & 807 \\
\hline u skladu je s vrijednostima društva & 283 & 3,88 & ,808 \\
\hline može doprinijeti učenicima tipičnog razvoja & 284 & 3,85 & ,775 \\
\hline Ukupno & 273 & 3,99 & ,610 \\
\hline \multicolumn{4}{|l|}{ Inkluzivno obrazovanje doprinosi razvoju učenika s teškoćama } \\
\hline kad je to moguće trebaju imati priliku boravka u redovnom razredu & 283 & 3,94 & 861 \\
\hline uključivanjem u redovni sustav razvijaju samostalnost & 284 & 3,51 & ,911 \\
\hline nije etično odvajati ih u posebne razrede & 284 & 3,30 & 1,111 \\
\hline izolacija u posebnim razredima ima negativan utjecaj na njihov socijalni i emocionalni razvoj & 283 & 3,28 & 1,076 \\
\hline unaprijedit će svoja obrazovna postignuća pohađanjem redovnog razreda & 284 & 3,26 & 880 \\
\hline Ukupno & 281 & 3,46 &, 747 \\
\hline
\end{tabular}

$\mathrm{N}=$ broj ispitanika, $\mathrm{M}=$ aritmetička sredina, $\mathrm{SD}=$ standardna devijacija

Na subskali Inkluzivno obrazovanje doprinosi razvoju tipičnih učenika, učitelji se slažu da inkluzivno obrazovanje "utječe na promicanje i prihvaćanje razlika kod drugih učenika”, "omogućava interakcije u miješanim skupinama koje potiču razumijevanje i prihvaćanje različitosti među učenicima", s ciljem razvoja "osjećaja socijalne prihvaćenost", usklađenosti "s vrijednostima društva" i mogućnosti da "doprinese učenicima tipičnog razvoja”.

Na subskali Inkluzivno obrazovanje doprinosi razvoju učenika s teškoćama učitelji se slažu da učenici s teškoćama trebaju boraviti u redovnom razredu kad je to moguće i da "uključivanjem u redovni sustav razvijaju samostalnost". Djelomično se slažu da je neetično odvajati ih $u$ posebne razrede, jer takva izolacija ima negativan utjecaj na njihov socijalni i emocionalni razvoj te da će unaprijediti svoja obrazovna postignuća pohađanjem redovnog razreda.

Učitelji se slažu da uključivanje učenika s teškoćama u redovne razrede doprinosi razvoju tipičnih učenika $(\mathrm{M}=3,99, \mathrm{SD}=0,61)$, a djelomično se slažu da doprinosi razvoju učenika s teškoćama $(\mathrm{M}=3,46, \mathrm{SD}=0,747)$.

Učiteljeva uvjerenja o inkluzivnim vrijednostima utječu na njegove stavove i postupke u poučavanju heterogene skupine učenika u razredu. Sukladno svojim uvjerenjima, učitelj u suvremenim razredima oblikuje okruženje za učenje svakog pojedinog učenika kako bi poticao razvoj njegovih sposobnosti, interesa i mogućnosti.

Kako bi se utvrdila latentna struktura skale Učiteljska uvjerenja o vrijednostima inkluzivnog obrazovanja, provedena je faktorska analiza. Ekstrakcijom faktora metodom najveće sličnosti ("maximum-likelihood"), uz oblimin rotaciju faktorskih osi, prema Gutman-Kaiserovom kriteriju i scree plotu, dobivena je faktorska struktura Učiteljskih uvjerenja o vrijednostima inkluzivnog obrazovanja (Tablica 2).

Faktorskom analizom na skali Uvjerenja učitelja o vrijednostima inkluzivnog obrazovanja dobivena su dva faktora (karakterističnih korijenova Lambda $=4,21$ odnosno 0.83 ), a postotak ukupno objašnjene varijance u odnosu na cjelokupan prostor manifesnih varijabli iznosio je 50,54\% (42,21\% za prvi i 8,35\% za drugi faktor).

Prvi faktor čini pet varijabli, s nejednako visokim saturacijama. Najviše saturacije na faktoru ima varijabla: inkluzivno obrazovanje "omogućava interakcije u miješanim skupinama koje potič razumijevanje i prihvaćanje različitosti među učenicima" $(0,925)$. Opisuje dobrobit za sve učenike uključene u inkluzivni razred koja proizlazi iz međusobnih interakcija učenika s teškoćama $i$ učenika tipičnog razvoja, a ogleda se u poveća- 
Tablica 2. Faktorska struktura Skale Uvjerenja učitelja o vrijednostima inkluzivnog obrazovanja

\begin{tabular}{|c|c|c|}
\hline $\begin{array}{l}\text { 1. Inkluzivno obrazovanje doprinosi razvoju tipičnih učenika } \\
\text { Inkluzija učenika s posebnim potrebama: }\end{array}$ & $\mathbf{h}^{2}$ & $\boldsymbol{\beta}$ \\
\hline $\begin{array}{l}\text { omogućava interakcije u miješanim skupinama koje potiču razumijevanje i prihvaćanje različitosti među } \\
\text { učenicima }\end{array}$ & ,767 & ,925 \\
\hline u skladu je s vrijednostima društva & ,557 & ,758 \\
\hline kao osnovni cilj ima osjećaj socijalne prihvaćenosti & ,311 & ,561 \\
\hline može doprinijeti učenicima tipičnog razvoja & 427 &, 548 \\
\hline utječe na promicanje i prihvaćanje razlika kod drugih učenika & ,493 &, 514 \\
\hline \multicolumn{3}{|l|}{$\begin{array}{l}\text { 2. Inkluzivno obrazovanje doprinosi kvaliteti obrazovanja učenika s teškoćama } \\
\text { Učenici s teškoćama: }\end{array}$} \\
\hline nije etično odvajati ih u posebne razrede & ,423 &, 705 \\
\hline uključivanjem u redovni sustav razvijaju samostalnost &, 591 & ,689 \\
\hline unaprijedit će svoja obrazovna postignuća pohađanjem redovnog razreda & 577 & ,660 \\
\hline izolacija u posebnim razredima ima negativan utjecaj na njihov socijalni i emocionalni razvoj & ,396 & ,656 \\
\hline kad je to moguće trebaju imati priliku boravka u redovnom razredu &, 513 & ,565 \\
\hline
\end{tabular}

h2-komunalitet, $\beta$ - faktorsko zasićenje iz matrice obrasca (prikazana su samo zasićenja veća od 0.3 )

nom međusobnom razumijevanju kao i prihvaćanju različitosti. Osrednja zasićenja na faktoru imaju varijable "inkluzija učenika s posebnim potrebama u skladu je s vrijednostima društva" $(0,758)$, koja opisuje proinkluzivan stav društva prema uključivanju učenika s teškoćama. Ostale tri varijable imaju zasićenja na faktoru od 0,514 do 0,561 . One opisuju socijalnu dimenziju uključivanja učenika $\mathrm{s}$ teškoćama u redovne razrede. Svih pet varijabli opisuju prednosti inkluzivnog odgoja i obrazovanja za sve učenike, naglašavajući dobrobit koja proizlazi iz međusobnih interakcija i društvenih vrijednosti, stoga je ovaj faktor nazvan Inkluzivno obrazovanje doprinosi razvoju tipičnih učenika.

Drugi faktor sadrži pet varijabli u kojima su saturacije ujednačene. Najviše saturacije na faktoru ima varijabla "učenike s teškoćama nije etično odvajati u posebne razrede" $(0,705)$. Varijabla opisuje neopravdanost i neetičnost odvajanja učenika s teškoćama u posebne razrede. Zasićenje na faktoru od 0,656 do 0,689 imaju varijable koje opisuju razvoj samostalnosti i akademsko napredovanje učenika s teškoćom u redovnom razredu i da izolacija u posebnim razredima utječe na njihov socijalni i emocionalni razvoj. Najniže saturacije ima varijabla "učenicima s teškoćama, kada je moguće, treba pružiti svaku priliku boravka u redovnom razredu" $(0,565)$, koja opisuje inkluzivno načelo i pravo učenika s teškoćama na pristup uključujućem, kvalitetnom i besplatnom osnovnom i srednjem obrazovanju na ravnopravnoj osnovi s drugima, u zajednicama u kojima žive (Konvencija o pravima osoba s invaliditetom, 2007, čl.24, 2.b). Svih pet tvrdnji u drugom faktoru opisuje koristi i dobrobiti uključivanja učenika s teškoćama u redovne razrede, pa je drugi faktor nazvan Inkluzivno obrazovanje doprinosi učenicimas teškoćama.

Inkluzivna praksa predstavlja filozofiju i vjerovanje da djecu s teškoćama treba uključiti u redovne škole (Friend i Bursuck, 2006) i temelj je razvoja pozitivnih stavova prema inkluziji. Učitelji generalno podržavaju inkluziju, ali rijetko prihvaćaju poučavati učenike s teškoćama (Cornoldi i sur., 1998; Scruggs i Mastropieri, 1996). Inkluzivno obrazovanje jest obrazovanje svih učenika u razredu, koji trebaju biti aktivno uključeni u proces učenja i poučavanja, a učitelj je odgovoran poučavati u skladu s kurikulumom i odgojno-obrazovnim potreba svakog učenika kako bi svi učenici u razredu mogli učiti. Nužna je promjena stava i vrijednosnih orijentacija svih odgojno-obrazovnih djelatnika, od tradicionalnog obrazovanja do onog inkluzivnog (Hrnjica, 2007). Učitelji se osjećaju osposobljenijima za rad s djecom koja zahtijevaju manje prilagodbe u inkluziji, dok se najmanje osposobljenima osjećaju za rad s djecom koja zahtijevaju značajne prilagodbe, primjerice s djecom s autizmom (Stoiber i sur., 1998). Učitelji uvježbani u korištenju strategija i intervencija za rad s učenicima s teškoćama te učitelji koji su promatrali djecu s različitim vrstama teškoća 
imaju pozitivnije stavove prema inkluziji (Cook i sur., 2007). Nespremnost učitelja za poučavanje ovih učenika povezana je s nedostatkom potrebnih materijala i dodatne podrške (Avramidis i Norwich, 2002). Učitelji koji podržavaju inkluziju spremniji su prilagoditi okruženje za učenje potrebama djece s teškoćama i koristiti različite prilagodbe i nastavne strategije (Ryan, 2009). Ranija istraživanja utvrdila su da na stavove učitelja prema poučavanju učenika s teškoćama utječu sljedeća socio-demografska obilježja učitelja: spol, dob, radni staž, studijski program i trajni profesionalni razvoj, kao i stupanj i vrsta teškoće (Forlin, 1995; Scruggs i Mastropieri, 1996).

\section{Učiteljska uvjerena o vrijednostima inkluzivnog obrazovanja u odnosu na dob, radni staž, županiju, vrstu i sadržaj studijskog programa}

Kako bi se utvrdilo postoje li razlike u učiteljskim uvjerenjima o vrijednostima inkluzivnog obrazovanja, u odnosu na dob, radni staž, županiju, vrstu i sadržaj studijskog programa, provedene su jednosmjerne analize varijance.

Postoji statistički značajna razlika u razini učiteljskih uvjerenja o prednostima inkluzivnog obrazovanja za sve učenike u odnosu na njihovu dob $(\mathrm{F}(1,267)=4,832 ; \mathrm{p}=0,003)$, godine radnog staža $(F(1,267)=5,715 ; p=0,04)$, razinu obrazovanja $(F(1,266)=5,683 ; p=0,018)$, županiju $(F(1,273)=11,814 ; p=0,001)$ i izjavu o odslušanom obveznom kolegiju za stjecanje kompetencija za rad $\mathrm{u}$ inkluzivnoj nastavi tijekom studija $(\mathrm{F}(1,266)=5,683 ; \mathrm{p}=0,018)$.

Učitelji mlađi od 40 godina i s manje od 20 godina radnog staža više se slažu s tvrdnjom da inkluzivno obrazovanje pogoduje tipičnim vršnjacima, u odnosu na učitelje starije od 50 godina i s više od 20 godina radnog staža. Niža kronološka dob prediktor je povoljnijih stavova učitelja prema inkluzivnom obrazovanju (Kiš - Glavaš i Wagner, 2001; Kiš-Glavaš, 1999). Iste nalaze dobili su Forlin i suradnici (2008): mlađi i manje iskusni učitelji skloniji su inkluziji, dok su njihovi stariji i iskusniji kolege više zabrinuti. Idol (2006) je, naprotiv, utvrdio da više radnog iskustva u inkluzivnoj nastavi utječe na učiteljevo bolje prihvaćanje učenika s teškoćama i kompetentnije tumačenje gradiva učenicima s različitim mogućnostima u učenju. Intuitivna uvjerenja temeljena na ranom osobnom obrazovnom iskustvu utječu na poimanje pristupa u učenju i odnosa učitelj-učenik (FeimanNemser, 2001). Učitelji s manje od 20 godina radnog staža sami su se školovali u razredima $i$

Tablica 3. Razlike u učiteljskim uvjerenjima o vrijednostima inkluzivnog obrazovanja s obzirom na socio-demografska obilježja

\begin{tabular}{|c|c|c|c|c|c|c|c|c|c|}
\hline \multirow{2}{*}{\begin{tabular}{|l|} 
Socio- \\
demografska \\
obilježja
\end{tabular}} & & \multicolumn{4}{|c|}{$\begin{array}{c}\text { Inkluzivno obrazovanje doprinosi } \\
\text { razvoju tipičnih učenika }\end{array}$} & \multicolumn{4}{|c|}{$\begin{array}{c}\text { Inkluzivno obrazovanje doprinosi } \\
\text { razvoju učenikas teškoćama }\end{array}$} \\
\hline & & $\mathbf{N}$ & M(SD) & F(ss) & $\mathbf{p}$ & $\mathbf{N}$ & M(SD) & F(ss) & $\mathbf{p}$ \\
\hline \multirow[t]{4}{*}{ Dob } & $<30$ & 29 & $4,12(0,62)$ & \multirow{4}{*}{$\begin{array}{l}4,83(3) \\
(1,2-4)^{*}\end{array}$} & \multirow[t]{4}{*}{$0,003^{* * *}$} & 30 & $3,54(0,68)$ & \multirow[t]{4}{*}{$2,136(3)$} & \multirow[t]{4}{*}{0,096} \\
\hline & $31-40$ & 94 & $4,08(0,57)$ & & & 98 & $3,58(0,66)$ & & \\
\hline & $41-50$ & 77 & $4,01(0,62)$ & & & 79 & $3,37(0,70)$ & & \\
\hline & $>50$ & 67 & $3,74(0,61)$ & & & 68 & $68(0,92)$ & & \\
\hline \multirow{3}{*}{$\begin{array}{l}\text { Godine } \\
\text { radnog staža }\end{array}$} & $<5$ & 49 & $4,15(0,60)$ & \multirow{3}{*}{$\begin{array}{l}5,72(2) \\
(1,2-3)^{*}\end{array}$} & \multirow[t]{3}{*}{$0,004 * *$} & 49 & $3,48(0,71)$ & \multirow[t]{3}{*}{$2,877(2)$} & \multirow[t]{3}{*}{0,058} \\
\hline & $6-20$ & 122 & $4,02(0,60)$ & & & 127 & $3,55(0,67)$ & & \\
\hline & $>20$ & 97 & $3,82(0,59)$ & & & 99 & $3,32(0,86)$ & & \\
\hline \multirow[t]{2}{*}{ Županija } & Primorsko-goranska & 231 & $3,93(0,62)$ & \multirow[t]{2}{*}{$11,82(1)$} & \multirow[t]{2}{*}{$\mid 0,001 * *$} & 239 & $3,41(0,75)$ & \multirow[t]{2}{*}{$7,686(1)$} & \multirow[t]{2}{*}{$0,006^{* * *}$} \\
\hline & Međimurska & 42 & $4,28(0,50)$ & & & 42 & $3,75(0,65)$ & & \\
\hline \multirow[t]{2}{*}{ Studij } & stručni & 109 & $3,88(0,63)$ & \multirow[t]{2}{*}{$5,68(1)$} & \multirow[t]{2}{*}{$0,018^{* *}$} & 111 & $3,38(0,78)$ & \multirow[t]{2}{*}{$1,611(1)$} & \multirow[t]{2}{*}{0,205} \\
\hline & sveučilišni & 157 & $4,06(0,59)$ & & & 162 & $3,50(0,72)$ & & \\
\hline \multirow{2}{*}{$\begin{array}{l}\text { Kolegij na } \\
\text { studiju }\end{array}$} & $\mathrm{Ne}$ & 176 & $3,92(0,59)$ & \multirow[t]{2}{*}{$5,92(1)$} & \multirow[t]{2}{*}{$0,016 * *$} & 181 & $3,38(0,76)$ & \multirow[t]{2}{*}{$6,932(1)$} & \multirow[t]{2}{*}{$0,009 * *$} \\
\hline & $\mathrm{Da}$ & 93 & $4,11(0,63)$ & & & 96 & $3,63(0,66)$ & & \\
\hline
\end{tabular}

$\mathrm{N}=$ broj ispitanika, $\mathrm{M}=$ aritmetička sredina, $\mathrm{SD}=$ standardna devijacija, $\mathrm{F}=$ omjer, $\mathrm{df}=$ stupnjevi slobode, $\mathrm{p}=*_{\mathrm{p}}<0,05^{* *} \mathrm{p}<0,01$ $* * * \mathrm{p}<0,001$; Post Hoc*- oznaka grupa od kojih se grupa u tom retku statistički značajno razlikuje uz Bonferoni korekciju za kontrolu Alpha pogreške pri višestrukim usporedbama u paru. 
školama u kojima su bili integrirani učenici s teškoćama, što je mogući razlog pozitivnog uvjerenja o prednostima zajedničkog školovanja.

Učitelji zaposleni u Međimurskoj županiji iskazuju višu razinu slaganja s tvrdnjom da inkluzivno obrazovanje doprinosi razvoju učenika s teškoćama, u odnosu na učitelje zaposlene u Primorskogoranskoj županiji. U ovom istraživanju sudjelovao je manji broj učitelja zaposlenih u Međimurskoj županiji, i to iz dviju prigradskih škola i jedne ruralne, od čega jedna škola ima preko 600 učenika, a dvije od 300 do 400 učenika. U većoj školi zaposleni su logoped, pedagog i edukacijski rehabilitator, koji čine stručni tim, u druge dvije pedagog, a učenicima $u$ jednoj od ovih škola pomoć povremeno pruža edukacijski rehabilitator ili socijalni pedagog. Neke škole u Primorsko-goranskoj županiji nemaju zaposlene navedene profile stručnjaka, pa bi u sljedećim radovima trebalo istražiti utjecaj dostupnosti stručne podrške učiteljima na uvjerenja o prednostima uključivanja učenika s teškoćama.

Učitelji sa sveučilišnim stupnjem obrazovanja izrazili su višu razinu slaganja s tvrdnjom da inkluzivno obrazovanje doprinosi razvoju tipičnih učenika, u odnosu na učitelje koji imaju stručni stupanj obrazovanja. Isto tako, učitelji koji su izjavili da su odslušali kolegij o poučavanju učenika u inkluzivnoj nastavi pokazuju višu razinu slaganja s tvrdnjom da inkluzivno obrazovanje doprinosi razvoju tipičnih učenika u razredu. S obzirom da je kolegij prisutan u studijskim programima najmanje 35 godina (Skočić Mihić, 2011; Wagner Jakubin, 2003), za očekivati je veći broj učitelja koji izvještava o zastupljenosti ovog kolegija u studijskom programu. Studenti koji su tijekom studiranja imali kolegij o inkluzivnom odgoju i obrazovanju više podržavaju inkluziju u odnosu na one koji nisu imali taj kolegij (Sunko, 2006). Uvjerenja odgajatelja o inkluziji povezana su s razinom obrazovanja (Stoiber i sur., 1998).

Učitelji se razlikuju u razini slaganja glede dobrobiti inkluzivnog obrazovanja za učenike s teškoćama samo s obzirom na županiju u kojoj rade $(\mathrm{F}(1,281)=7,686 ; \mathrm{p}=0,006)$ i izjavu o odslušanom obveznom kolegiju za stjecanje kompetencija za rad u inkluzivnoj nastavi tijekom studija $(\mathrm{F}(1,277)=6,932 ; \mathrm{p}=0,009)$. Statistički značajno nižu razinu slaganja glede prednosti inkluzivnog obrazovanja za sve učenike imaju učitelji stariji od 50 godina u odnosu na učitelje mlađe od 40 godina. Također, učitelji koji navode da su odslušali obvezni kolegij za stjecanje kompetencija za rad u inkluzivnoj nastavi tijekom studija pokazuju višu razinu slaganja s tvrdnjom da inkluzivno obrazovanje doprinosi učenicima s teškoćama, u odnosu na one koji ga nisu slušali. Učitelji koji su osposobljeni za rad s djecom s teškoćama pozitivnije sagledavaju inkluziju djece s teškoćama (UNICEF, 2013).

Od učitelja se očekuje da efikasno/učinkovito poučavaju sve učenike neovisno o njihovim sposobnostima, mogućnostima i interesima te da promoviraju toleranciju i socijalnu povezanost, efikasno odgovaraju na potrebe učenika s teškoćama i idu ukorak s novim znanjima i pristupima u poučavanju, učenju i procjeni (OECD, 2005). Inkluzivni model nije moguće provesti ako stručnjaci u praksi nisu pripremljeni kroz inicijalni i trajni profesionalni razvoj. Učitelji nisu dovoljno pripremljeni tijekom inicijalnog obrazovanja za rad $\mathrm{u}$ inkluzivnoj nastavi i razumijevanje potreba djece s teškoćama (Conderman i Johnston-Rodriguez, 2009). Stoga se manji broj njih osjeća kompetentnima, što upućuje na zaključak o potrebi znatnih promjena u obrazovnom kurikulumu ovih stručnjaka (Bouillet, 2008). Iako je prošlo više od 20 godina od uvođenja inkluzivnog obrazovanja, inicijalno obrazovanje učitelja i dalje sadrži samo jedan obvezni kolegij. Indikativno je da mnogi navode da nisu odslušali kolegij, iako su ga gotovo svi imali u studijskom programu. Uspješno inkluzivno obrazovanje temelji se na premisi da učitelji vjeruju da učenici s teškoćama mogu akademski i socio-emocionalno napredovati u redovnim razredima, pri čemu najveći utjecaj ima znanje učitelja o poučavanju ovih učenika. Stoga, sukladno brojnim istraživanjima, i ovo apostrofira značaj koje inicijalno obrazovanje ima u osposobljavanju učitelja za poučavanje u inkluzivnim razredima, pa iako je inkorporirano u različite zakonske propise i dalje se učitelji obrazuju samo kroz jedan obvezni kolegij za rad s ovim učenicima. Neophodno je promišljati o jačanju studijskih programa većim brojem kolegija koji osposobljavaju studente za kvalitetnu provedbu inkluzije (Skočić Mihić i sur., 2014).

Conderman i Johnston-Rodriguez (2009) apostrofiraju da je glavna odgovornost u oblikovanju 
stava i vještina učitelja potrebnih za inkluziju i suradnju na inicijalnom obrazovanju učitelja, kao i oblikovanju pozitivnih stavova prema djeci s teškoćama (Sze, 2009). Studijski programi ne trebaju biti orijentirani samo na znanje o poučavanju, već bi trebali osigurati način na koji studenti razumiju vrijednosti, razvijaju stavove i uvjerenja te prate svoj profesionalni razvoj (Leavy i sur., 2007). Osobito je važno da studenti sudjeluju na vježbama i stječu praktična iskustva rada s učenicima $\mathrm{s}$ teškoćama tijekom inicijalnog obrazovanja te da su mentorirani od strane kvalificiranih odgajatelja i supervizirani od sveučilišnih profesora (National Commission on Teaching and America's Future, 1996; prema Conderman, Johnston-Rodriguez, 2009). Pozitivni stavovi i kvalitetna osposobljenost određuju uspješnost inkluzije i učenika s teškoćama (Avramidis i Norwich, 2002; Kudek Mirošević i Jurčević Lozaninčić, 2014), pa je nužno osigurati kvalitetne studijske programe i dovoljan broj kolegija za osposobljavanje, kako studenata, tako i zaposlenih učitelja (Schmidt i Vrhovnik, 2015). Uvjerenja učitelja o tome mogu li se u inkluzivnim razredima oblikovati razredna ozračja koja doprinose i tipičnim učenicima i učenicima s teškoćama, duboko su ukorijenjena i ovisna o kontekstualnim čimbenicima. Tako stariji učitelji s više godina radnog staža i završenim stručnim studijem, školovani u tradicionalnom školskom sustavu koji je karakterizirala socijalna isključenost učenika s teškoćama, vide manje prednosti suvremenog inkluzivnog obrazovanja u odnosu na mlađe. S druge strane, učitelji koji se izjašnjavaju da su tijekom studija pohađali jedan obvezni kolegij u kojem su stjecali kompetencije za poučavanje u inkluzivnoj nastavi, uvjereniji su da inkluzivno obrazovanje promovira inkluzivne vrijednosti u zajednici i doprinosi kako tipičnim učenicima, tako i učenicima s teškoćama u njihovom akademskom i socijalnom razvoju.

\section{ZAKLJUČAK}

Rezultati ovog istraživanja jasno diferenciraju učiteljska uvjerenja o vrijednostima inkluzivnog obrazovanja za razvoj, s jedne strane učenika s teškoćama, a s druge tipičnih vršnjaka. Pri tome se slažu da je vrijednost ovog obrazovanja u tome što doprinosi razvoju učenika bez teškoća, a djelomično i radi doprinosa razvoju učenika s teškoća- ma, čime je prva hipoteza djelomično potvrđena. Također, djelomično je potvrđena i druga hipoteza kojom se pretpostavilo da postoje statistički značajne razlike u uvjerenjima učitelja s obzirom na dob, radni staž, vrstu i sadržaj studija, očekujući višu razinu inkluzivnih vrijednosti kod učitelja niže kronološke dobi i više razine obrazovanja, dok se razlike nisu očekivale s obzirom na županiju. Pokazalo se, sukladno postavljenim hipotezama, da mlađi učitelji s manje radnog staža, više razine obrazovanja i zastupljenim kolegijem o inkluzivnom obrazovanju u studijskom programu smatraju kako inkluzivno obrazovanje doprinosi razvoju tipičnih učenika. Suprotno postavljenoj nultoj hipotezi, rezultati su pokazali razlike između učitelja u odnosu na županiju u kojoj rade. Učitelji zaposleni u Međimurskoj županiji pokazuju višu razinu inkluzivnih vrijednosti, pa bi u daljnjim istraživanjima trebalo utvrditi utječe li na ovaj nalaz uistinu samo lokacija županije ili medijator varijable kao što su pružena podrška stručnih suradnika, veličina razreda, broj učenika s teškoćama i slično. Također, suprotno postavljenim hipotezama kad se radi o učiteljevom uvjerenju da inkluzivno obrazovanje doprinosi razvoju učenika s teškoćama, ne postoje statistički značajne razlike u odnosu na sociodemografske značajke učitelja, osim pripadnost županiji i zastupljenosti kolegija kojim se osposobljavaju za rad u inkluzivnoj nastavi. Rezultati ovog istraživanja, kao i mnogobrojnih drugih, nedvojbeno upućuju na osobiti značaj koji kvalitetni studijski programi imaju u osposobljavanju budućih učitelja za uspješno nošenje s izazovima poučavanja u inkluzivnim razredima. Uspješna inkluzija nije moguća bez kvalitetno osposobljenih učitelja s kompetencijama, pozitivnim stavovima i uvjerenjima koja promoviraju inkluzivne vrijednosti.

Ograničenja ovog istraživanja su prije svega zastupljenost učitelja dominantno iz jedne županije, što sužava mogućnost generalizacije. Također, otvara se pitanje jesu li učitelji bili skloni davanju socijalno poželjnih odgovora, osobito kad su ispunjeni upitnik predavali stručnim suradnicima u školama. Upitno je postojanje medijator varijabli, kojima bi se moglo preciznije utvrditi koji elementi iz okuženja posreduju učiteljska uvjerenja. 


\section{LITERATURA}

Avramidis, E., Norwich, B. (2002): Teacher attitudes towards integration/inclusion: a review of the literature. European Journal of Special Needs Education, 17, 2, 129-147.

Beijaard, D., Meijer, P. C., Verloop, N. (2004): Reconsidering research on teachers' professional identity. Teaching and Teacher Education 20, 107-128.

Bouillet, D. (2008): Ključne kompetencije u odgoju i obrazovanju djece s teškoćama u razvoju: U Pedagogija i društvo znanja, 2. međunarodna konferencija u Zadru, 13.-15. studenog, 37-45. Zagreb: Učiteljski fakultet Sveučilišta u Zagrebu.

Kudek Mirošević, J. (2015): Učenici s teškoćama i izazovi obrazovne prakse. Hrvatski časopis Za Odgoj I Obrazovanje, $17,2,11-26$.

Conderman, G., Johnston-Rodriguez, S. (2009): Beginning Teachers' Views of Thir Collaborative Roles. Preventing School Failure, 53(4), 235-244.

Cornoldi, C., Terreni, A., Scruggs, T. E., Mastropieri, M. A. (1998): Teacher Attitud es in Italy After Twenty Years of Inclusion. Remedial and Special Education, 19, 3, 350-356.

Cook, B. G., Cameron, D. L., Tankersley, M. (2007): Inclusive Teachers' Attitudinal Ratings of Their Students With Disabilities. The Journal of Special Education, 40,4, 230-238.

Domović, V., Vizek Vidović, V. (2013): Uvjerenja studentica učiteljskoga fakulteta o ulozi učitelja, učenika i poučavanju. Sociologija I Prostor, (Institut za društvena istraživanja u Zagrebu), 493-508.

Državni pedagoški standard osnovnoškolskog sustava odgoja i obrazovanja (2008): Narodne novine br.63/ 2008.

EURLex, 2009: Council Conclusions on a strategic framework for European cooperation in education and training "ET 2020"

Everington, C., Stevens, B., Winters, V. B. (1999): Teachers' attitudes, felt competence and need of support for implementation of inclusive educational programs. Psychological Reports, 85, 331-338.

Farrell, P. (1997): Teaching Pupils with Learning Difficulties. London: Cassell

Feiman-Nemser, S. (2001): From Preparation to Practice: Designing Continuum to Strenghten and Sustain Teaching. Teachers College Record, 103, 6, 1013-1055.

Florian L., Linklater H. (2010): Preparing teachers for inclusive education: using inclusive pedagogy to enhance teaching and learning for all, Cambridge Journal of Education, 40, 4, 369-386.

Forlin, C. (1995): Educators' beliefs about inclusive practices in Western Australia. British Journal of Special Education, $22,4,179-185$.

Forlin, C., Keen, M., Barrett, E. (2008): The concerns of mainstream teachers: Coping with inclusivity in an Australian context. International Journal of Disability, Development and Education, 55, 3, 251-264.

Friend, M., Bursuck, W. D. (2006): Including Students with Special Needs. A Practical Guide for Classroom Teachers. Boston: Allyn\&Bacon.

Hrnjica, S. (2007): Djeca s razvojnim teškoćama u redovnim osnovnim školama u Srbiji: trenutno stanje i stavovski preduslovi za potencijalnu inkluziju: Istraživačka studija. Beograd.

Idol, L. (2006): Toward Inclusion of Special Education Students in General Education: A Program Evaluation of Eight Schools. Remedial and Special Education, 27 (2), 77-94.

Ivančić, Đ. (2010): Diferencirana nastava u inkluzivnoj školi. Zagreb: Alka script.

Karić, T., Mihić, V., Korda, M. (2014): Stavovi profesora razredne nastave o inkluzivnom obrazovanju dece sa smetnjama u razvoju. Primjenjena Psihologija, 7,4, 531-548.

Kiš-Glavaš, L. (1999): Promjena stava učitelja prema učenicima usporenog kognitivnog razvoja. Doktorska disertacija. Zagreb: Edukacijsko rehabilitacijski fakultet Sveučilišta u Zagrebu. 
Kiš - Glavaš, L., Wagner, A. (2001): Stavovi učitelja prema poučavanju kao determinante promjena stavova prema integraciji učenika usporenog kognitivnog razvoja. Revija Za Rehabilitacijska Istraživanja, 37, 2, 191-202.

Korthagen, F.A.J., Lagerwerf, B. (1996): Reframing the relationship between teacher thinking and teacher behaviour: levels in learning about teaching. Teachers and Teaching: theory and practice 2(2), 161-190.

Korthagen, F. A. J. (2004): In search of the essence of a good teacher: towards a more holistic approach in teacher education. Teaching and Teacher Education, 20, 77-97.

Kosnik, C., Beck, K. (2009): Priorities in Teacher Education. London and New York: Routledge.

Kudek Mirošević, J., Jurčević Lozančić, A. (2014): Stavovi odgajatelja i učitelja o provedbi inkluzije u redovitim predškoskim ustanovama i osnovnim školama. Hrvatska revija za rehabilitacijska istraživanja, 50, 2, 17-29

Leavy, A. M., McSorley, F. A., Boté, L. A. (2007): An examination of what methaphor construction reveals about the evolution of preservice teachers` beliefs about teaching and learning. Teaching and teacher education, 23, $1217-1233$.

Linn, M, Coelho da Silva, J. (2014): Inclusion: Teacher attitudes in Portugal and the United States. Poster Presentation at Conference "Embracing inclusive approaches for children and youth with special needs," Braga, 14-17-07.2014, 37.

Ministarstvo znanosti, obrazovanja i športa (2011): Nacionalni okvirni kurikulum za predškolski odgoj i obrazovanje te opće obvezno i srednjoškolsko obrazovanje, Zagreb: Ministarstvo znanosti, obrazovanja i športa RH.

Ministarstvo znanosti, obrazovanja i športa (2015): Nacionalni kurikulum za rani i predškolski odgoj i obrazovanje: Narodne novine, 5/2015.

Olsen, B. (2008): Teaching what they learn, learning what they live. Boulder, CO: Paradigm Publishers.

OECD. (2005): Teachers Matter: Attracting, Developing and Retaining Effective Teachers. Education And Training (Vol. 31). Posječeno 15.12.2015. na http://www.nefmi.gov.hu/letolt/nemzet/oecd_publication_teachers_matter_ english_061116.pdf

Pavri, S., Hegwer-DiVita, M. (2006): Meeting social and emotional needs of students with mild disabilities:, The special educators' perspective. Reading and Writing Quarterly, 22, 2, 139 - 153.

Pravilnik o osnovnoškolskom i srednjoškolskom odgoju i obrazovanju učenika s teškoćama u razvoju (2015): Narodne novine, 24/2015.

Rafferty, Y., Boettcher, C., i Griffin, K. W. (2010): Benefits and risks of reverse inclusion for preschoolers with and without disabilities: Parents' perspectives. Journal of Early Intervention, 24, 266-286.

Richardson, V. (1996): The role of attitude and beliefs in learning to teach. In J. Sikula (Ed.), Handbook of research on teacher education (pp. 102-119). New York: Macmillan.

Ryan, T. G. (2009): Inclusive attitude: A pre-service analysis. Journal of Research in Special Educational Needs, 9, 3, 180-187.

Samuel, M., Stephens, D. (2000): Critical dialogues with self: developing teacher identities and roles- a case study of south African Student teachers. International Journal of Educational research, 33, 475-491.

Sunko, E. (2006): Gledišta studenata učiteljskih i nastavničkih studija o integraciji i inkluziji djece s posebnim potrebama. Napredak, 147,2, 209-221.

Scruggs, T. E., Mastropieri, M. A. (1996): Teacher perceptions of mainstreaming-inclusion, 1958-1995: A research synthesis, Exceptional Children, 63 (1), 59-74.

Skočić Mihić, S. (2011). Spremnost odgajatelja i faktori podrške za uspješno uključivanje djece s teškoćama u rani i predškolski odgoj i obrazovanje.Doktorska disertacija. Edukacijsko-rehabilitacijski fakultet, Zagreb.

Skočić Mihić, S., Lončarić, D., Rudelić, A. (2011): Volontiranje studenata s djecom i mladima s posebnim odgojnoobrazovnim potrebama. Ljetopis Socijalnog Rada, 18(3), 579-600. 
Skočić Mihić, S., Lončarić, D., Kolombo, M., Perger, S., Nastić, M., Trgovčić, E. (2014): Samoprocijenjene kompetencije studenata učiteljskog studija za rad s djecom s posebnim odgojno-obrazovnim potrebama. Napredak, $155,3,303-322$.

Stoiber, K. C., Gettinger, M., Goetz, D. (1998): Exploring Factors Influencing Parents' and Early Childhood Practitioners" Beliefs about Inclusion. Early Chikllto Research Quaderly, 13, 1, 107-124.

Schmidt, M., Vrhovnik, K. (2015): Stavovi nastavnika prema inkluziji djece s posebnim potrebama u osnovne i srednje škole. Hrvatska revija za rehabilitacijska istraživanja, 51(2), 16-30.

Sze, S. (2009): A Literature Review: Pre-service Teachers' Attitudes Toward Students with Disabilities. Education, 130-1, 53-56.

UNICEF (2013): Stanje djece u svijetu 2013.- Sažetak. Djeca s teškoćama u razvoju. Posječeno na stranicama UNICEF-a 12.12.2015. na http://www.unicef.hr/upload/file/382/191254/FILENAME/Djeca_s_teskocama_ HR_6_13_w.pdf

Wagner Jakubin, A. (2003): Informiranost studenata učiteljskih studija o učenicima s posebnim potrebama i neke njihove osobine u odnosu na stavove preme edukacijskoj integraciji. Edukacijsko-rehabilitacijski fakultet Sveučilišta u Zagrebu.

Zakon o odgoju i obrazovanju u osnovnoj i srednjoj školi (2008): Narodne novine, 87/08, 86/09, 92/10, 105/10, 90/11, $16 / 12,86 / 12,126 / 12,94 / 13,152 / 14$.

Zakon o potvrđivanju Konvencije o pravima osoba s invaliditetom i fakultativnog protokola uz Konvenciju o pravima osoba s invaliditetom (2007): Narodne novine, 80.

Zheng, H. (2009): Areview of Research on EFL Pre-Service Teachers` Beliefs and

Practices. Journal of Cambrige Studies, 4,1, 73-81.

Žic Ralić, A., Ljubas, M. (2013): Prihvaćenost i prijateljstvo djece i mladih s teškoćama u razvoju. Društvena istraživanja, 22, 3, 435-453.

Winter, E. (2006): Preparing New Teachers for Inclusive Schools and Classrooms. Support for Learning, Vol. 21, No. 2, 85-91.

\section{TEACHERS' BELIEFS ABOUT THE VALUES OF INCLUSIVE EDUCATION}

\footnotetext{
Abstract: The education policy in Croatia is inclusive and therefore promotes inclusive values in the community. Teachers beliefs about and attitudes towards inclusive education play a key role in the successful education of students with disabilities in regular classes. This paper is based on the hypothesis that teachers - especially younger and less-experienced teachers, as well as elementary school teachers - believe that inclusive education contributes equally to the development of students with disabilities and to the development of typical students..

The study included 274 teachers from two counties in the Republic of Croatia. Questionnaire on Teachers' Opinions about the Inclusion of Children with Moderate to Severe Special Needs in General Education Settings (Linn and Coelho da Silva, 2014) was used. By significant reduction of the variables, a Scale of Teacher Beliefs about Inclusive Values with good metric characteristics was obtained. It included two factors: (1) Inclusive education contributes to the development of typical students and (2) Inclusive education contributes to the development of students with disabilities.
}

Key words: Inclusive education, teachers, teachers'beliefs 